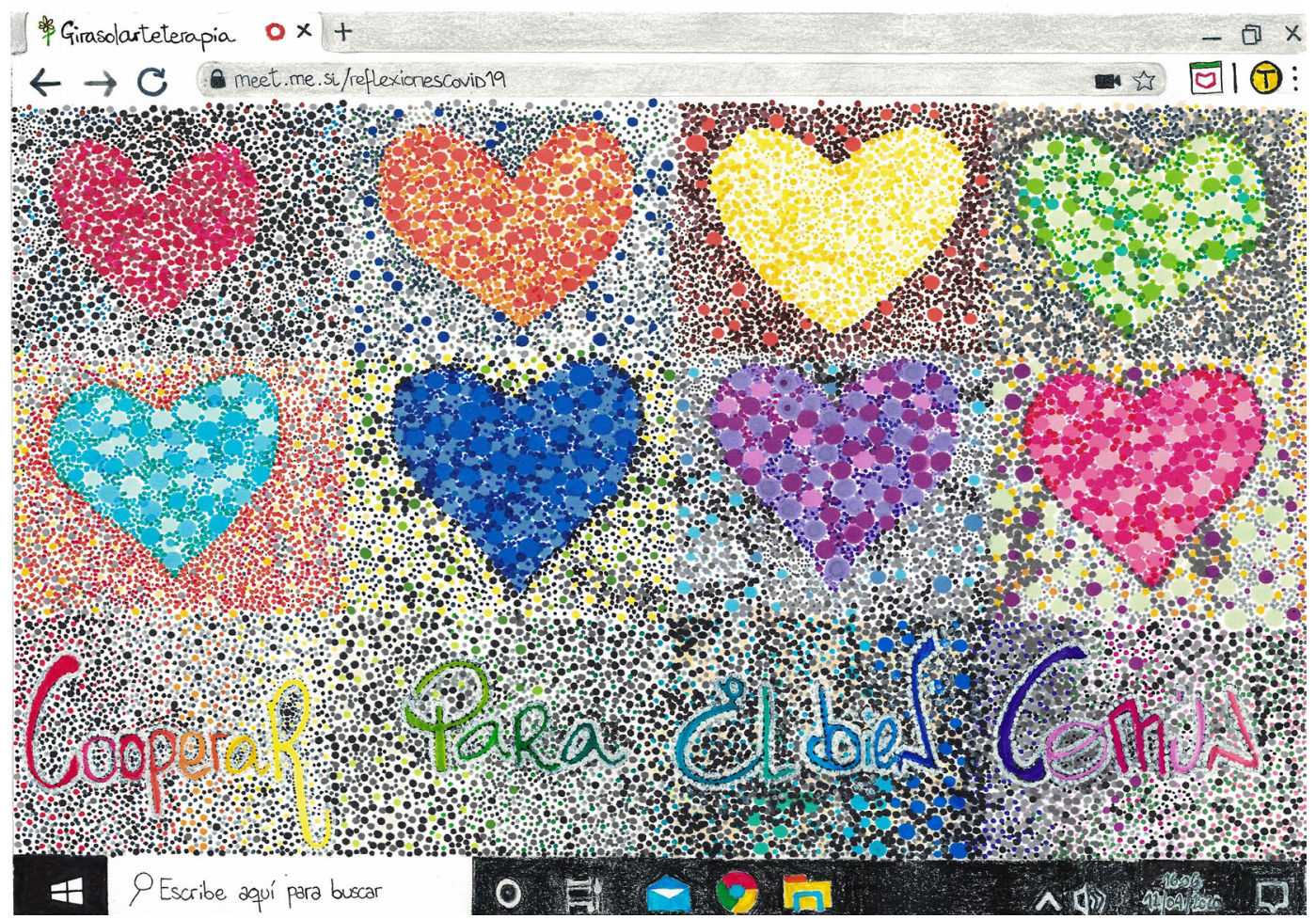

\title{
Cooperar para el bien común
}

\section{Reflexión}

Video-llamadas en casa para comunicarnos con quienes están lejos aun queriéndoles cerca. Pantallas que facilitan relacionarnos, trabajar, estudiar, emocionarnos... porque, en la distancia, sentimos corazones asomando tras ventanas virtuales.

Mientras, desde otras ventanas, niños y niñas cuelgan arco-iris dibujados que nos apelan a "COOPERAR PARA EL BIEN COMÚN" y contribuir, así, a su convicción de que \#Todo va a salir bien en tiempos del Covid19.

\section{Autora}

Tania Ugena Candel

Girasol Arteterapia en Movimiento

arteterapia@girasolarteterapia.es

Socia de AFIA

Máster de Arteterapia (UCM)

Arteterapia: papeles de arteterapia y educación artística para la integración social.

Monográfico: Las miradas del arte y el arteterapia en tiempos de la Covid19. ISSN-e: 1988-8309

https://dx.doi.org/10.5209/arte.75892 